\title{
MENINGKATKAN KEMAMPUAN KOGNITIF MELALUI KEGIATAN MENGKLASIFIKASI BENDA DALAM TIGA KATEGORI (BENTUK, WARNA DAN UKURAN) DI KELOMPOK B TK NEGERI LALOWARU
}

\author{
Aisyah $^{1)}$, Intan Wardany Ranat Amry ${ }^{1)}$, Salim $^{2) *}$ \\ ${ }^{1}$ Jurusan PG-PAUD, Universitas Halu Oleo. Jln. H.E.A Mokodompit, Kendari 93232, Indonesia. \\ ${ }^{2}$ Jurusan Pendidikan Matematika, Universitas Halu Oleo. Jln. H.E.A Mokodompit, Kendari 93232 , \\ Indonesia.
}

*Korespondensi Penulis. E-mail: salimpsa@gmail.com, Telp: 085341614860

\begin{abstract}
Abstrak
Penelitian ini bertujuan untuk mengetahui peningkatan kemampuan kognitif melalui kegiatan mengklasifikasikan benda dalam tiga kategori di TK Negeri Lalowaru Kecamatan Moramo Kabupaten Konawe Selatan. Jenis penelitian ini adalah Penelitian Tindakan Kelas. Subjek dalam penelitian ini adalah guru dan anak Kelompok B TK Negeri Lalowaru Kecamatan Moramo Kabupaten Konawe Selatan yang berjumlah 15 orang anak laki-laki. Berdasarkan hasil tentang kemampuan kognitif anak melalui kegiatan pengelompokkan benda menunjukkan bahwa terdapat peningkatan. Hal ini dapat dibuktikan pada hasil observasi awal diperoleh persentase $27 \%$, pada siklus I diperoleh persentase 53\%, dan pada siklus II di peroleh persentase ketuntasan 87\%. Dengan demikian dapat disimpulkan bahwa kemampuan kognitif anak di Kelompok B TK Negeri Lalowaru Kecamatan Moramo Kabupaten Konawe Selatan dapat ditingkatkan melalui kegiatan mengklasifikasikan benda dalam tiga kategori (bentuk, warna dan ukuran).
\end{abstract}

Kata kunci: Kemampuan Kognitif, Mengklasifikasikan Benda, Anak

\section{INCREASING THE COGNITIVE ABILITY OF CHILDREN THROUGH CLASSIFYING ACTIVITIES IN THREE CATEGORIES (SHAPE, COLOR AND SIZE) IN GROUP B TK NEGERI LALOWARU}

\begin{abstract}
This study aims to determine the improvement of cognitive abilities through the activities of classifying objects in three categories in TK Negeri Lalowaru District Moramo Kabupaten Konawe Selatan. This type of research is Classroom Action Research. Subjects in this study were teachers and children Group B TK Negeri Lalowaru Moramo District South Konawe District which amounted to 15 studens. Based on the results of the cognitive abilities of children through the activities of grouping of objects shows that there is an increase. This can be proven on the results of initial observations obtained percentage of $27 \%$, in the cycle I obtained a percentage of $53 \%$, and in cycle II obtained $87 \%$ percentage of mastery. Thus it can be concluded that the cognitive abilities of children in Group B TK Negeri Lalowaru District Moramo Kabupaten Konawe Selatan can be improved through the activity of classifying objects in three categories (shape, color and size).
\end{abstract}

Keywords: Cognitive Ability, Classifies Objects, Children.

\section{PENDAHULUAN}

Pendidikan Anak Usia Dini (PAUD) adalah suatu upaya pembinaan yang ditujukan kepada anak sejak lahir sampai dengan usia 6 tahun yang dilakukan melalui pemberian rangsangan pendidikan untuk membantu pertumbuhan dan perkembangan jasmani dan rohani agar anak memiliki kesiapan dalam memasuki pendidikan lebih lanjut (Dikdasmen, $2010: 1)$.

Berdasarkan Undang-Undang Nomor 20 Tahun 2003 tentang Sistem Pendidikan Nasional Pasal 1 angka 14 menyebutkan bahwa 
Pendidikan Anak Usia Dini (PAUD) adalah suatu upaya pembinaan yang ditujukan kepada anak sejak lahir sampai dengan usia 6 tahun yang dilakukan melalui pemberian rangsangan pendidikan untuk membantu pertumbuhan dan perkembangan jasmani dan rohani agar anak memiliki kesiapan dalam memasuki pendidikan lebih lanjut (Dikdasmen, 2010 : 1). Cakupan program pembelajaran Pendidikan Anak Usia Dini (PAUD) dalam Permendiknas No. 58 Tahun 2009 meliputi bidang pembentukan perilaku yang terdiri dari dua lingkup aspek perkembangan yaitu nilai-nilai agama dan moral (NAM) dan sosial emosional, dan bidang kemampuan dasar yang terdiri dari tiga lingkup perkembangan yaitu aspek berbahasa, kognitif dan fisik.

Aspek perkembangan anak harus dikembangkan sejak dini yakni ketika masa peka atau The Golden Age (0-8 tahun) dimana aspek kemampuan anak berkembang dengan pesat. Salah satu aspek perkembangan anak yang sangat penting untuk dikembangkan adalah perkembangan kognitif. Tujuan dari pengembangan kognitif adalah untuk mengembangkan kemampuan berpikir anak untuk dapat mengolah apa yang telah diajarkan padanya, berlatih memecahkan masalah, mengembangkan kemampuan logika matematis dan pengetahuan akan ruang dan waktu, serta mempunyai kemampuan untuk memilah-milah, mengelompokkan, serta mempersiapkan kemampuan berpikir secara teliti (Dikdasmen, $2010: 18$ ).

Salah satu konsep matematika yang dikembangkan pada anak usia dini adalah belajar mengklasifikasi. Klasifikasi merupakan salah satu kemampuan yang penting untuk diajarkan pada anak karena klasifikasi merupakan salah satu tahapan awal anak untuk belajar berpikir secara logis, yakni anak akan belajar mengenai aturan yang jelas dalam mengelompokkan benda pada saat mengklasifikasikan benda. Kemampuan klasifikasi tidak tumbuh begitu saja pada diri seseorang, namun perlu dibangun sejak dini. Anak harus sudah mulai diasah kemampuan klasifikasi dalam hal yang konkret berdasaran warna, bentuk, dan ukuran. Misalnya, dimulai dari melatih anak membereskan mainan berdasarkan jenis, bentuk, warna dan ukuran.

Berdasarkan hasil observasi di TK Negeri Lalowaru Kecamatan Moramo Kabupaten Konawe Selatan dalam hal kemampuan klasifikasi benda dalam 3 kategori kurang di pahami oleh anak, disebabkan oleh kurangnya penggunaan media pembelajaran yang digunakan guru sangat terbatas, dalam pembelajaran guru hanya menjelaskan tanpa mempraktekkan langsung. Berdasarkan permasalahan yang terjadi di TK Negeri Lalowaru Kecamatan Moramo Kabupaten Konawe Selatan peneliti tertarik untuk meneliti secara langsung proses pembelajaran yang ada di TK Negeri Lalowaru Kecamatan Moramo Kabupaten Konawe Selatan sebagai salah satu cara untuk meningkatkan kemampuan kognitif melalui kegiatan mengklasifikasikan benda dalam tiga kategori pada anak kelompok B TK Negeri Lalowaru Kecamatan Moramo Kabupaten Konawe Selatan.

Berdasarkan uraian latar belakang tersebut, maka rumusan masalah dalam penelitian ini yaitu bagaimana meningkatkan kemampuan kognitif melalui kegiatan mengklasifikasikan benda dalam tiga kategori di TK Negeri Lalowaru Kecamatan Moramo Kabupaten Konawe Selatan. Mengacu pada rumusan masalah penelitian ini untuk mengetahui peningkatan kemampuan kognitif anak melalui kegiatan mengklasifikasikan benda dalam tiga kategori pada anak kelompok B di TK Negeri Lalowaru Kecamatan Moramo Kabupaten Konawe Selatan

\section{METODE}

Jenis penelitian yang digunakan dalam penelitian ini adalah penelitian tindakan kelas (classroom action research). Menurut Sa'dun (2010: 28), Penelitian Tindakan Kelas (PTK) adalah proses investigasi terkendali untuk menemukan dan memecahkan masalah pembelajaran di kelas, proses masalah tersebut dilakukan bersiklus yang bertujuan untuk meningkatkan kualitas pembelajaran dan hasil pembelajaran di kelas.

Arikunto, dkk (2011: 56) mendefinisikan Penelitian Tindakan Kelas (PTK) merupakan penelitian tindakan (action research) yang dilakukan dengan tujuan memperbaiki mutu praktik pembelajaran di kelasnya.

Penelitian ini telah dilaksanakan di Taman Kanak-kanak Negeri Lalowaru Kecematan Moramo Utara Kabupaten Konawe Selatan. Penelitian Tindakan Kelas ini di laksanakan pada semester ganjil tahun pelajaran 2017/2018 yaitu pada Bulan NovemberDesember 2017. Subjek penelitian tindakan 
kelas ini adalah seluruh anak kelompok B yang berjumlah 15 anak.

Pengolahan data dalam penelitian ini disesuaikan dengan teknik penelaian di TK yaitu dengan mengunakan data sebagai berikut: *= Belum Berkembang (BB), $\quad * *=$ Mulai Berkembang (MB), ***= Berkembang Sesuai Harapan (BSH), $* * * *=$ Berkembang Sangat Baik (BSB), Depdiknas (2004). Adapun rumus yang di gunakan yaitu, sebagai berikut:

1. Keberhasilan anak secara individual. Dengan rumus:

$$
\begin{aligned}
& \text { (jumla } h \text { nilai } B S B)+(\text { jumla } h \text { nilai } B S H)+ \\
& \text { Nilai }=\frac{(\text { jumla } h \text { nilai } M B)+(\text { jumla } h \text { nilai } B B)}{\text { jumla } h \text { seluru } h \text { item }} \\
& \text { x } 100 \%
\end{aligned}
$$

2. Untuk mengetahui persentase keberhasilan anak didik secara klasikal, dengan rumus:

$$
\text { jumla } h \text { anakmemperole } h \text { nilai }
$$$$
\begin{aligned}
\text { Presentase } & =\frac{\text { konvensi } " B S B \text { dan } B S H "}{\text { banyaknya anak didik }} \\
& \text { x } 100 \%
\end{aligned}
$$

Tabel 1. Kategori Keberhasilan Secara Individual

\begin{tabular}{clc}
\hline Interval & \multicolumn{1}{c}{ Kategori } & $\begin{array}{c}\text { Simbol } \\
\text { Bintang }\end{array}$ \\
$3,50-4,00$ & $\begin{array}{l}\text { Berkembang Sangat } \\
\text { Baik (BSB) }\end{array}$ & $* * *$ \\
Berkembang Sesuai & $* * *$ \\
& $\begin{array}{l}\text { Harapan (BSH) } \\
1,50-2,49\end{array}$ & $\begin{array}{l}\text { Mulai Berkembang } \\
\text { (MB) }\end{array}$ \\
$0,01-1,49$ & $\begin{array}{l}\text { Belum Berkembang } \\
\text { (BB) }\end{array}$ \\
\hline & \multicolumn{3}{c}{ (Depdiknas, 2004:26) }
\end{tabular}

\section{HASIL DAN PEMBAHASAN}

Kemampuan anak melalui kegiatan mengklasifikasi benda dalam tiga kategori (bentuk, warna dan ukuran) di kelompok B TK Negeri Lalowaru mengalami peningkatan yang cukup signifikan. Hal ini terlihat dari persentase awal yang dapat mendapat kategori Berkembang Sangat Baik (BSB) hanya sebesar 7\% atau sebanyak 1 anak. Pada siklus I persentase yang didapat sebesar $20 \%$ atau sebanyak 3 anak. Dan pada siklus II persentase keberhasilan klasikal mencapai $40 \%$ atau sebanyak 6 anak.

Berkaitan dengan kendala yang dihadapi pada siklus I diantaranya yaitu kurangnya kemmpuan peneliti dalam mengelola kelas sehingga masih banyak anak yang kurang memperhatikan kegiatan pembelajaran mengenai mengklasifikasi benda melalui tiga kategori (bentuk, warna dan ukuran) yang diberikan peneliti. Kemudian setelah dilakukannya perbaikan pada siklus II yaitu peneliti mulai terampil dalam mengelola kelas maka anak tersebut sangat memperhatikan guru bahkan sangat antusias dalam mengikuti proses pembelajaran melalui kegiatan mengklasifikasi benda dalam tiga ketegori (bentuk, warna dan ukuran). Setelah melihat hasil persentase kemampuan kognitif anak sebagaimana tertera pada refleksi siklus II, bahwa kegiatan mengklasifikasi benda dalam tiga kategori (bentuk, warna dan ukuran) dapat meningkatkan kemampuan kognitif anak.

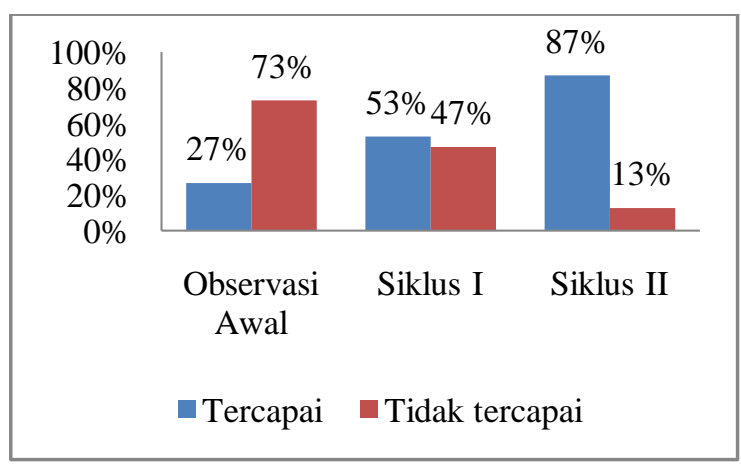

Gambar 1. Hasil Analisis Kemampuan Kognitif anak melalui Kegiatan Mengklasifikasikan Benda dalam Tiga Kategori (bentuk, waran dan Ukuran)

Dalam meningkatkan kemampuan kognitif melalui kegiatan mengklasifikasi benda dalam tiga kategori (bentuk, warna dan ukuran), disusun dan dilaksanakan secara baik dan optimal oleh peneliti yang berkolaborasi dengan guru kelompok B TK Negeri Lalowaru Kecamatan Moramo Utara Kabupaten Konawe Selatan. Penelitian ini dikatakan berhasil karena persentase peningkatan kemampuan kognitif melalui kegiatan mengklasifikasi benda dalam tiga kategori (bentuk, warna dan ukuran) pada siklus II mencapai 87\%, maka penelitian ini dapat dihentikan.

Adanya kegiatan pengklasifikasian benda dalam tiga kategori (bentuk, warna dan ukuran) menjadikan siswa terbiasa dalam mengasah kemampuan kognitifnya. Pembiasaan kegiatan pengklasifikasian ini akan meransang kognitif anak sehingga anak akan melakukan tahapan kegiatan pembelajaran dengan semakin leih baik. 


\section{SIMPULAN DAN SARAN}

\section{Simpulan}

Berdasarkan hasil observasi yang dilakukan pada anak kelompok B TK Negeri Lalowaru Kecamatan Moramo Utara Kabupaten Konawe Selatan kemampuan kognitif anak mengalami peningkatan yang cukup signifikan. Hal ini terlihat dari adanya peningkatan pada observasi awal sebesar $27 \%$. Tingkat keberhasilan yang dicapai pada siklus I adalah sebesar $53 \%$, sedangkan pada siklus II telah mencapai persentase keberhasilan sebesar $87 \%$. Olah karena itu, dapat disimpulkan bahwa kegiatan mengklasifikasi benda dalam tiga kategori (bentuk, warna dan ukuran) dapat meningkatkan kemampuan kognitif anak.

Saran

Saran dalam penelitian ini yaitu perlu perbaikan kualitas pembelajaran yang diterapkan guru TK selama ini dan dapat menjadikan kegiatan mengklasifikasi benda dalam tiga kategori (bentuk, warna dan ukuran) sebagai aktivitas pembelajaran untuk meningkatkan kognitif anak.

\section{DAFTAR PUSTAKA}

Arikunto, Suharsimi. 2011. Penelitian Tindakan Kelas. Jakarta: Bumi Aksara.

Depdiknas. 2004. Kurikulum Tahun 2004: Kurikulum Berbasis Kompetensi. Jakarta : Depdiknas.

Paul, Suparno. 2001. Teori Perkembangan Kognitif Jean Piaget. Yogyakarta: Penerbit Kanisius.

Sa'dun, Akbar. 2010. Prosedur Penyusunan Laporan dan Artikel Hasil Penelitian Tindakan Kelas. Yogyakarta: Cipta Media.

Slamet, Suyanto, 2005. Konsep Dasar Pendidikan Anak Usia Dini. Jakarta: Dirjen Dikti Depdiknas 